\title{
Gestualidade ancestral: \\ o trânsito entre 0 \\ Candomblé e o teatro
}

\author{
Ancestral gestuality: the traffic between Candomblé \\ and the theater
}

Daniela Bany Polito Moraes ${ }^{1}$

1.

Mestra pelo Programa de Pós-Graduação em Artes Cênicas pela Universidade Federal do Rio Grande do Norte/UFRN.

ORCID: http://orcid.org/

0000-0001-9284-8938

Contato:

daniela.beny@gmail.com para o diálogo acadêmico, a partir do estudo dos autores Zeca Ligiéro, Richard Schechner e Diana Taylor, os possíveis caminhos para a preparação do artista da cena partindo das motrizes culturais afro-ameríndias como forma de restauração de comportamento e a transmissão de conhecimento incorporado.

Palavras-chave: Estudos afro-ameríndios. Antropologia da Performance. Candomblé.

\section{ABSTRACT}

Through understanding the use of the body and orality as a means of transmitting knowledge within Candomblé, this article aims to discuss in academic dialogue - using the studies of the authors Zeca Ligiéro, Richard Schechner and Diana Taylor - the possible methods of scene artist preparation using Afro-Amerindian cultural motifs as a way of restoring behaviour and the transmission of incorporated knowledge. Keywords: Afro-Amerindian Studies. Performance Anthropology. Candomblé. 
Nas sociedades ocidentais de origem/influência judaico-cristã se estabeleceu que a transmissão de conhecimento se daria por meio da escrita, necessitando assim que os sujeitos envolvidos no binômio ensino-aprendizagem fossem minimamente letrados, capazes, desta forma, de compreender os códigos ali escritos. É preciso lembrar, porém, que na nossa composição da sociedade brasileira o modo de transmissão dos saberes passa pelas práticas corporais herdadas dos povos afro-ameríndios. Essa constatação nos leva a um diálogo direto com a antropóloga Diana Taylor (2013), que defende o conceito de conhecimento incorporado - sobre o qual nos debruçaremos melhor posteriormente - como uma das principais formas de transmissão de conhecimento dos povos afro-ameríndios, dadas as características da estrutura dessas culturas. Segundo a professora Dra. Inaicyra Falcão dos Santos (2008),

O estudo da ancestralidade yorubá, o respeito à memória das comunidades-terreiro, o diálogo com suas matrizes míticas, nos fortalece enquanto nação brasileira, ajudando-nos a compreender melhor a nossa cultura, valorizando as nossas diversidades. A arte da dança, enquanto linguagem do sensível tem nos possibilitado uma vivência rica em conteúdos que norteiam o processo criativo (SANTOS, 2008, p. 01)

Partindo desta premissa, pretendemos partilhar aqui a experiência do trânsito da prática da dança de Iansã desde o Xirê ${ }^{2}$, passando pelos espetáculos do Afoxé ${ }^{3}$ Oju Omim Omorewá ${ }^{4}$ até as salas de ensaio. É importante salientar que o objetivo não é levar para a cena a representação do Orixá tal qual ela ocorre no ambiente litúrgico; aqui, a codificação corporal de sua dança será ressignificada para o ambiente artístico como uma possibilidade de acesso à gestualidade ancestral já presente em cada artista, mas que, porventura, parece estar adormecida ou ignorada.

Aproximações entre o Candomblé e o teatro:

o Orixá que dança-canta-conta

Antes de apontar os procedimentos metodológicos propriamente ditos, é importante salientar que parte do desenvolvimento epistemológico desta investigação toma com base - a princípio intuitivamente e depois com fundamentação teórica - os estudos da Performance defendidos pelos antropólogos Diana Taylor e Richard Schechner, os quais ambos propõem que "as performances funcionam como atos de transferências vitais, transmitindo o conhe-
2 . "(...) o Xirê é a designação geral usada para nominar a sequência de danças rituais dos candomblés, que começa com Exu e é finalizada com Oxalá. Segue-se uma ordem pré-estabelecida, como se fosse um roteiro teatral, reunindo orixás afins: das águas, da terra, da caça, da criação do mundo, numa ordem funcional e que atende aos significados prescritos pelo modelo yorubá (LODY, SABINO, 2011, p. 103)"

3.

"Afoxé é um cortejo de rua que tradicionalmente sai no carnaval (...) É importante observar nessa manifestação os aspectos místico, mágico e por conseguinte religioso. Apesar dos afoxés apresentarem-se aos olhos dos menos entendidos como um simples bloco carnavalesco, fundamentam-se os praticantes em preceitos religiosos ligados aos cultos dos orixás, motivo primeiro da existência e realização dos cortejos. Por isso, afoxé também é conhecido e chamado por Candomblé de Rua (...) Apesar de todas as modificações e desfigurações, esses grupos procuram manter valores e características de 'africanidade' como: cânticos em dialetos africanos (...) utilização de cores e símbolos que possuem significados específicos dentro dos preceitos religiosos dos terreiros de candomblé (LODY, 1976, p. 3)"

4.

Grupo sediado em Maceió/AL, fundado em 2009, composta pelos artistas Daniela Beny (Atriz, dramaturga, diretora e produtora), Marco Antonio de Campos (Encenador, diretor, cenógrafo, figurinista e produtor), Arnaldo Ferju (Ator, contador de histórias, cenógrafo, aderecista e iluminador) e Erick Silva (cenógrafo, cenotécnico, fotógrafo e vídeomaker), além de artistas convidados para compor elenco e equipe técnica. Montagens: "Voo ao Solo" (2009), "A cor da chuva" (2011 - contemplado com o Prêmio de Incentivo à Produção e Circulação de Projetos em Artes Cênicas em Alagoas, Secretaria de Estado da Cultura de Alagoas e Fundação Universitária de Extensão e Pesquisa) e "Rosas, carroças e dramas" (2012 - contemplado pelo Programa de Cultura Banco do Nordeste/BNDES - Edição 2012, categoria Artes Integradas ou Não-Específicas com o projeto "Rosas, carroças e dramas", Banco do Nordeste Brasileiro e BNDES). 
cimento, a memória e o sentido de identidade social" (TAYLOR, p. 27, 2013), sendo esta forma de transmissão considerada como conhecimento incorporado.

Como metodologia de investigação deste trânsito foram propostas três etapas, sendo elas: Observação, En/incorporação e Condução. Salientamos que essas etapas, em determinados momentos da pesquisa, ocorreram de modo concomitante e que foram fundamentais para entender o processo de transição entre cada um desses ambientes.

Como Observação considera-se a etapa de pesquisa de campo, acompanhando ensaios do Afoxé e saída-de-orixás ${ }^{5}$ com o intuito de gravar vídeos e fotografar, mapeando as características de movimento da Dança de Iansã no contexto do sagrado e do artístico, percebendo diferenças e convergências.

En/incorporação denota a etapa da investigação em que a pesquisadora, além de vivenciar a dança de Iansã em estado de transe, também experimentou aulas da dança de Iansã com a coreógrafa do Afoxé Oju Omim Omorewá e em sequência buscou retomar em sala de ensaio individualmente estes elementos apresentado durante as aulas, mas adaptados para uma proposição de treinamento ${ }^{6}$ para atores e atrizes, corporificando assim o que iria propor como uma possibilidade de acesso à gestualidade ancestral colaborando para o processo de criação cênica, restaurando comportamentos. Cabe aqui já introduzirmos o conceito de Richard Schechner (2003), ao explicar que

Comportamento restaurado é simbólico e reflexivo. Seus significados têm que ser decodificados por aqueles que possuem conhecimento para tanto (...) Tornar-se consciente do conhecimento restaurado é reconhecer o processo pelo qual processos sociais, em todas as suas formas, são transformados em teatro, fora do sentido limitado da encenação de dramas sobre um palco (SCHECHNER, 2003, p. 35).

A compreensão do termo Comportamento Restaurado nesta pesquisa serve como base para o que estamos considerando como Gestualidade Ancestral, pois se trata da tomada de consciência do/a artista cênico/a do seu potencial corpóreo-energético que aflora por meio do estímulo de elementos pouco considerados no corpo cotidiano.

Após a Observação e a En/Incorporação, a próxima etapa trata-se da Condução, que nada mais é do que uma compilação do que foi visto e apreendido e que agora será compartilhado com voluntários/as, sejam eles alunos/as dos cursos de Mestrado e/ou graduação da Universidade à qual esta pesquisa está relacionada ou participantes de projeto de extensão da mesma instituição.
5.

Saída pública do médium incorporado com seu Orixá, esta saída ocorre durante o Xirê e normalmente está associada ou à iniciação do médium ou em cerimônia de aniversário de feitura do santo.

6.

Apesar de ser um termo muito controverso, aqui tomamos como base o conceito de Savarese (2012), propondo que "Ao mesmo tempo em que o treinamento se propõe como uma preparação física ligada ao ofício, também é uma espécie de crescimento pessoal para o ator que vai para além do nível profissional. É um meio para controlar o próprio corpo e orientá-lo com segurança, e é também a conquista de uma inteligência física (SAVARESE, 2012, p. 293)". 
Em linhas gerais, podemos apontar que o trânsito da codificação corporal da dança de Iansã e de seus elementos se dá da seguinte maneira: Saída-de-Orixá $\rightarrow$ Afoxé $\rightarrow$ Laboratórios Individuais $\rightarrow$ Sala de ensaio.

Como ponto de partida desse trânsito, a codificação corporal dentro deste contexto é compreendida inicialmente como

[...] elemento de comunicação da coreografia, através do qual aspectos do arquétipo do Orixá são observados e reconhecidos. Esta significação da codificação corporal é re-significada quando sua execução quanto dança sai do espaço sagrado dos terreiros e ocupa o espaço do palco/rua/salas de ensaio; cabendo à pesquisa problematizar e discutir a apropriação no campo secular de um elemento sagrado, uma vez que o corpo é de fundamental importância para o Candomblé e a Umbanda por ser o meio em que se dá o contato/comunicação entre o plano espiritual e o plano material (BENY, 2014).

Especificamente nesta pesquisa, a codificação corporal ajudará a compreender a categorização dos movimentos e a relação entre eles e os elementos litúrgicos da dança e seus elementos dramáticos e, consequentemente, como transmissores de conhecimento de uma comunicação não verbal, pois, mesmo sendo o Candomblé uma religião pautada na tradição oral, o que se observa é que na corporeidade da Dança de Orixá tanto o movimento da dança quanto o gestual estão intimamente ligados aos itans ${ }^{7}$, pois, segundo Zenicola (2011), "Os signos corporais traduzem sentimentos e atos dos homens, são códigos impressos de suas realizações intelectuais e espirituais, memórias de si e do seu grupo ancestral (ZENICOLA, 2011, p. 89)".

Ao relocar o corpo codificado religioso para as artes, inclusive como um processo de potencialização para que o artista da cena melhore o desenvolvimento do seu ofício, recorremos aqui a um recorte de Eugenio Barba (2012, p. 230) ao definir que "A codificação corporal é uma consequência visível dos processos fisiológicos do ator, para dilatá-los e para produzir um equivalente das mecânicas e das forças que funcionam na vida. A codificação é formalização".

Embora Barba proponha que a codificação é formalização, o uso do corpo nesta prática foge do que podemos considerar como formal já que o objetivo é que o indivíduo explore sua corporeidade a partir de estímulos específicos, mas sem abandonar o que faz parte de seu repertório corporal, já que "o corpo é nosso meio geral de ser no mundo" (MERLEAU-PONTY, 1999, p. 203). Se pretendemos acessar a Gestualidade Ancestral, não podemos ignorar as histórias de vida que cada um dos corpos carrega em si.
7.

Termo em iorubá para o conjunto de todos os mitos, canções e histórias componentes da cultura iorubá, podendo vir grafado itã. 
Cabe lembrar que nesta investigação o corpo do médium em transe pode - e deve - ser pensado como o local onde ocorre um procedimento litúrgico, e, por conseguinte, sagrado, também pode se considerar que este corpo dançante durante o transe é responsável pela corporificação de elementos que manifestam forças da natureza, questão a ser detalhada adiante. Portanto, temos aqui dois usos do corpo dentro da religiosidade, porém, ao observar as ações dentro do ambiente sagrado tomando como referencial a vivência artística e projetando uma metodologia de trabalho a partir da dança religiosa, percebemos que não se trata de uma dança pela dança, que durante o Xirê cada Orixá conta sua história, partilha com os espectadores o seu drama tal como propõe o filósofo Johan Huizinga (2008), pois

O ritual é um dromenon, isto é, uma coisa que é feita, uma ação. A matéria desta ação é um drama, isto é, uma vez mais, um ato, uma representação num palco. Esta ação pode revestir a forma de um espetáculo ou de uma competição. O rito, ou "ato ritual", representa um acontecimento cósmico, um evento dentro do processo natural. Contudo, a palavra "representação" não exprime o sentido exato da ação, pelo menos na conotação mais vaga que atualmente predomina; porque aqui "representação" é realmente identificação, a repetição mística ou a reapresentação do acontecimento. O ritual produz um efeito que, mais do que figurativamente mostrado, é realmente reproduzido na ação. Por tanto, a função do rito está longe de ser simplesmente imitativa, leva a uma verdadeira participação no próprio ato sagrado (HUIZINGA, 2008, p. 18).

Então, para além da prática corporal como uma forma de transmissão de conhecimento e possibilidade de perpetuação de saberes, as características particulares do Xirê nos aproximam do teatro pelos elementos performáticos presente nos mesmos, além dos aspectos de espetacularidade que giram em torno dos paramentos e figurinos específicos de cada Orixá, no uso de músicas específicas de chamamento, firmeza e saída de cada divindade e principalmente na presença de uma plateia que se dirige ao espaço sagrado do terreiro como quem dirige-se ao teatro para assistir um espetáculo.

Na tradição iorubá, segundo o senso comum dos praticantes do Candomblé, o corpo é compreendido como um microcosmos e cada parte deste corpo desenvolverá uma função específica dentro do campo simbólico da dança executada em diálogo com a espiritualidade. Este mesmo corpo que dança no transe traz em sua codificação a escrita dos itans de cada Orixá; assim sendo, ao tomar a dança de Iansã como ponto de partida para o acesso à ancestralidade adormecida em cada indivíduo, estamos também trazendo do 
terreiro para a sala de ensaio outros elementos que versam sobre o Orixá em questão, compreendendo a corporeidade dentro de um contexto em que se dança-canta-conta-batuca as lendas iorubanas.

Antes de qualquer aprofundamento para discutirmos conceitos e processos epistemológicos, é necessário compreender que Orixá é este ao qual nos referimos. Inicialmente, propõe-se aqui o entendimento de Orixá como a personificação de uma força da natureza em terra. Dito isto, podemos então considerar que Iansã é uma deusa que toma o corpo do médium em transe para materializar o vento, a tempestade, o fogo e o raio. Tendo como referência estes fenômenos naturais, caracteriza-se que a personalidade de Iansã corresponde a uma pessoa intempestiva, corajosa, curiosa, inquieta e ativa, sendo ela adjetivada dessa maneira em vários de seus itans que relatam seus feitos.

Além disso, uma das funções desempenhadas por Iansã no mundo espiritual é o trânsito dos eguns (espírito dos mortos) do Aiê (mundo material) para o Orum (mundo espiritual). Para executar essa função, Iansã utiliza dois instrumentos, o eruexim - uma espécie de abanador feito com crina de cavalo, remetendo à ideia da cauda de um búfalo - e o chicote. Cada um desses instrumentos será manipulado durante a execução da dança no momento do transe mediúnico, onde com o eruexim Iansã trará movimentos de abanar o espaço, formando os ventos e promovendo a transformação do lugar e com o chicote ela açoitará esses espíritos desencarnados no sentido de os obrigar a deixar o mundo dos vivos.

Dentro das muitas lendas de Iansã algumas contam da sua capacidade de transformação em outros seres vivos como a Borboleta e o Búfalo. É interessante observar que esses dois seres apresentam características físicas completamente opostas, sendo um facilmente associado à metamorfose, delicadeza e suavidade, enquanto o outro se associa à terra, ao vigor físico, à força, à brutalidade. Esses seres também estão presentes na Dança de Iansã quando em terra no médium em transe.

Todos esses aspectos e características da Dança de Iansã foram observados durante a saída-de-orixá e os ensaios do Afoxé, porém, só com as aulas da Dança de Iansã foi possível a apropriação e ressignificação dos movimentos, possibilitando assim que os mesmos fossem categorizados e organizados de forma a propor uma metodologia para acesso à Gestualidade Ancestral. Cabe aqui considerar que, segundo Santos (2008),

[...] a criação do intérprete define-se primeiro como ato de comunicação, pois o mesmo é, antes de tudo, o produtor de sua obra, construída por meio de signos de natureza gestual e sonora. $\mathrm{O}$ 
intérprete se transforma no próprio signo. Percebe-se que o corpo, em cena, revela a dimensão expressiva, a dimensão orgânica. (...) Pretende-se, a princípio, a procura pela essência, pelas raízes ritualísticas que carregamos como seres humanos e, num segundo momento, a procura pelas narrativas míticas, a razão de ser das tradições. Momento este que envolve a construção de imagens, a percepção de sentimentos; possibilita abertura para um corpo criativo e imaginativo que articule as matrizes corporais, a memória e a sua expressividade. É o momento que se instaura, pela obra, o elo da tradição e da contemporaneidade na diversidade das culturas (SANTOS, 2008, p. 1).

Por compreender e buscar aproximação com essas raízes ritualísticas, a categorização e organização desses três elementos foram relacionados à dança/mitologia de Iansã foram o Vento, a Borboleta e o Búfalo. Seria possível, nessa escolha, eleger outros elementos relacionados à Iansã, como o Bambuzal, a Coruja, o Carneiro, mas uma série de especificidades permearam o processo de en/incorporação da pesquisadora, como o fato dos três elementos já citados serem os que se sobressaíram nas observações de campo.

A escolha destes elementos nessa ordem se deu pela suposta neutralidade do Vento - que pode variar desde uma brisa até uma tempestade - e pela oposição energética entre a Borboleta e o Búfalo, podendo ser trabalhado em sala de ensaio uma variação entre as qualidade de energia Anima e Animus que possibilitaria aos/às participantes experimentarem estados de conforto ou desconforto, potencializando o trabalho artístico e ampliando o repertório corporal do/a intérprete.

Ao me referir à energia-Anima e à energia-Animus me reporto novamente a Barba (2009) quando o mesmo aponta que

Energia-Anima (suave) e energia-Animus (vigorosa) são termos que não tem nada a ver com a distinção de masculino-feminino, nem com os arquétipos de Jung. Refere-se a uma polaridade pertinente à anatomia do teatro, difícil de se definir com palavras e, portanto, difícil de se analisar, desenvolver e transmitir. Entretanto, dessa polaridade e o modo com que o ator chega a dilatar seu território dependem as suas possibilidades de não cristalizar-se numa técnica mais forte que ele (BARBA, 2009, p. 102-103).

Ainda considerando os aspectos da Energia-Anima e da Energia-Animus, é necessária a compreensão concreta das características da Dança de Iansã proposta a partir desses três elementos, então, sendo assim, podemos propor o seguinte quadro, tomando como referência a experiência da pesquisadora durante a etapa de En/Incorporação. 


\begin{tabular}{|l|l|l|l|l|l|}
\hline $\begin{array}{l}\text { Personagem } \\
\text { [Eu-Elemento] }\end{array}$ & $\begin{array}{l}\text { Tipo de } \\
\text { Energia }\end{array}$ & $\begin{array}{l}\text { Sensação } \\
\text { do Corpo }\end{array}$ & $\begin{array}{l}\text { Nível de } \\
\text { Dificuldade } \\
\text { na Execução }\end{array}$ & $\begin{array}{l}\text { Posição } \\
\text { dos Pés }\end{array}$ & $\begin{array}{l}\text { Movimentos } \\
\text { dos Braços }\end{array}$ \\
\hline BORBOLETA & Anima & Leveza & Intermediário & Meia ponta & Soltos \\
\hline BÚFALO & Animus & Peso & Fácil & $\begin{array}{l}\text { Espalmados } \\
\text { no chão }\end{array}$ & Retos \\
\hline VENTO & Anima & Flutuação & Difícil & Meia ponta & Circulares \\
\hline
\end{tabular}

Além das informações contidas acima, a Dança de Iansã acaba tendo como característica fundamental a polirritmia, o que leva à dissociação dos membros superiores dos inferiores. Embora o Vento, o Búfalo e a Borboleta sejam diferentes entre si, esse aspecto da execução se mantém, porém respeitando as singularidades de cada qualidade de energia.

Numa breve descrição, poderíamos dizer que a execução da coreografia da Dança de Iansã associada ao elemento Vento se dá com cotovelos que ficam erguidos na altura dos ombros, com as mãos abertas para fora, o movimento dos braços será circular como se estivesse espalhando algo, sempre de dentro para fora, punhos soltos para que haja fluidez no movimento das mãos, peito com esterno aberto, queixo posicionado na linha do horizonte com a cabeça acompanhando o movimento da coluna, tronco levemente inclinado para trás enquanto os quadris estão levemente inclinados para frente. Os pés se mantêm apoiados grande parte do tempo na ponta, espalmado por completo no chão apenas para a transferência de peso nas passadas. Os deslocamentos são sinuosos, apontando para todas as direções. Há uma dissociação dos movimentos dos ombros e dos quadris, como se seguissem em direções opostas, porém não muito acentuada, podendo assim haver a polirritmia das ações.

Esses movimentos associados às atividades que Iansã desenvolve no plano espiritual estão diretamente relacionados à ação de espantar os eguns e à limpeza dos ambientes.

No que diz respeito ao movimento do Búfalo, mais especificamente no momento do ataque, o animal se posiciona alguns passos para trás para tomar distância e atacar seu alvo. O deslocamento de ataque é direto, e no retorno para a posição inicial os passos são dados para trás, nunca virando as costas para quem foi atacado.

Diferentemente dos movimentos de vento, as ações do búfalo trazem as mãos como se protegessem o tronco, com cotovelos apontados para fora, as mãos abertas e retas espalmadas para fora também, o esterno continua aberto e o tronco levemente inclinado para trás, a cabeça permanece parte do tempo apontando 
para a linha do horizonte, mas sem pender para os lados. Os pés estão completamente apoiados no solo e, por consequência, todas as ações relacionadas à batalha nas coreografias da Dança de Iansã os pés estão espalmados, sugerindo assim a relação com o búfalo e sua firmeza na terra.

Para a Borboleta, as ações se associam à sinuosidade pelos movimentos leves e expansivos como quem se mostra, os pés passarão parte do tempo nas pontas com pequenos saltos e os joelhos levemente flexionados. Braços farão movimentos que sugerem asas, acentuando as articulações dos ombros, cotovelos e punhos, partindo desde a clavícula que, em oposição ao esterno, abre e fecha peito e costas.

Como parte do repertório da Dança de Iansã, podemos incluir também o Quebra-Louças e as danças que sugerem o uso de alguns paramentos, como a espada e o eruexim ${ }^{8}$. Embora essas danças não tenham sido o foco da investigação, é importante compartilhá-las, pois, tanto no laboratório individual quanto na sala de ensaio alguns desses gestos foram acessados e se fizeram presentes durante as improvisações.

No Quebra-Louças, consideramos a representação do Búfalo como base, porém a principal diferença da postura é a direção do movimento das mãos, sugerindo que estão jogando pratos no chão, mantem-se a oposição entre ombros e quadris, os joelhos ficam levemente flexionados e os pés espalmados na transferência de peso.

Ao se investigar a codificação corporal da dança com a espada, percebemos a interação de Iansã com Ogum, podendo essa coreografia ser considerada como uma variação da sua representação do Búfalo, sendo assim a posição dos pés se mantém, porém a modificação será a execução dos movimentos dos braços.

Os braços continuarão como se estivessem protegendo o tórax, porém agora os braços parecerão espadas/facões, num movimento lateral sugerindo o corte da vegetação para abrir caminho, por exemplo, e quando a ação é executada orientada para frente, um braço assumirá a postura de espada e o outro uma postura de escudo.

A dança com o eruexim possui algumas peculiaridades, primeiro porque há a interação com as características de movimentos da Dança de Oxóssi, que consiste no trote dos pés, fazendo com que a caminhada seja mais acelerada com os pés apoiados principalmente na ponta e com pequenos saltos também.

O tronco inclina-se formando uma diagonal entre quadris e ombros, mantendo assim a oposição dessas duas partes do corpo.

Com os punhos relaxados e as mãos soltas, os braços se agitam
8.

Ferramenta litúrgica assemelhada a um espanador, seu cabo é geralmente de madeira e as cerdas são feitas de pelos da crina de bois ou cavalos. Dentro do contexto simbólico do Candomblé é uma ferramenta utilizada por Iansã e Oxossi para espantar os eguns. 
como se espanassem algo, sendo o próprio eruexim; os cotovelos ficam erguidos na altura dos ombros e os movimentos são executados em todas as direções. Quadris e peito se deslocam para frente e para trás, do mesmo modo que as costas, aumentando assim a sensação de desequilíbrio.

Observando essas características é possível então propor uma aproximação dos usos do corpo no ambiente sagrado - ou fortemente influenciado por ele, como no caso das coreografias do Afoxé - com as práticas corporais vivenciadas/experimentadas no teatro.

Vários teóricos poderiam oferecer suporte ou ser referência para esse diálogo, por isso mesmo optamos aqui por aproximar essa categorização/descrição da Dança de Iansã com os elementos que são base da Antropologia Teatral, pesquisada e difundida por Eugenio Barba - tendo como princípios o equilíbrio precário, a dança das oposições, a incoerência coerente, a equivalência, a omissão/absorção das ações e o sats - porém aqui os conceitos e observações desses princípios serão a partir do ponto de vista da pesquisadora, atriz e diretora Luciana Saul, que em 2006 apresentou a dissertação "Rituais do Candomblé - uma inspiração para criativo do ator", na Universidade de São Paulo/USP sobre o processo de criação do espetáculo "Itãs Odu Medéia". Optamos por este olhar pela aproximação com minha pesquisa e por ser ela uma das poucas autoras que recorrem às práticas do Candomblé como base do trabalho de preparação de atores/atrizes. Para Saul

O equilíbrio precário relaciona-se com o controle de uma posição de instabilidade - isto gera novas tensões e resistência no corpo, produzindo uma nova tonicidade muscular, propiciando a dilatação da presença cênica em um corpo-em-vida. Trata-se de deformar, conscientemente, o equilíbrio, gerando uma permanente instabilidade, mesmo na imobilidade. A imobilidade passa a ser dinâmica, ou seja, há constantes reajustes de tensões e pressões nos apoios dos pés (SAUL, 2006, p. 21).

Pensando nos aspectos que compõem o princípio do equilíbrio precário, podemos traçar um paralelo com a Dança de Iansã em relação ao contato dos pés com o chão, onde boa parte do tempo os pés permanecem em meia ponta, subindo o foco de atenção, encontraremos os joelhos flexionados e os quadris em movimentos circulares ou em oito. Tratando-se da parte inferior do corpo isso já exige do/a atuante outra organização corporal, não só força e resistência dos grupos musculares das pernas, mas também do abdômen e atenção especial à coluna que mantém em harmonia e equilíbrio o corpo, o que faz com que se observe a dança das oposições. 
A dança das oposições relaciona-se com forças antagônicas percebidas nas oposições das partes do corpo, na oposição de energias diferentes, na oposição na efetuação da ação, na oposição entre equilíbrio e assimetria ou ainda entre repouso e movimento (SAUL, 2006, p. 21).

Oposição e assimetria podem também designar a Dança de Iansã, justo por ter como característica a polirritmia e as constantes mudanças de direção é possível observar que os movimentos da cintura pélvica para baixo obedecem uma direção e da cintura pélvica para cima outra, os pés marcam um tempo, enquanto ombros, cotovelos e punhos rotacionam os membros superiores noutra velocidade e mesmo que os dois braços executem movimentos que sigam o mesmo princípio, não há o sentido de simetria, assim sendo, já é possível observar aqui a incoerência coerente que, segundo Saul (2006, p. 22) "relaciona-se com a incoerência da ação em relação à logica cotidiana, tanto em função da economia de energia, como em relação à artificialidade do comportamento cênico", pois tantos nas atividades cotidianas quanto na Dança de Iansã se executa a ação de espanar - por exemplo - mas no segundo caso, além de ser utilizada mais energia, o movimento tende à estilização.

Esses três princípios aqui indicados já existem por si só na Dança de Iansã, seja como performance artística ou religiosa, e levando em consideração suas características, cabem muito bem ao "treinamento" de ator/atriz do modo que estamos propondo e que abordaremos mais a frente, então, vivenciando os elementos da Dança de Iansã em laboratório, seja na etapa de en/incorporação ou de Condução, é possível chegar aos outros três princípios , sendo assim, para o trabalho do/a ator/atriz a experiência desses elementos faz com que se busque o princípio da equivalência que, como aponta Saul (2006, p.22) "relaciona-se com o deslocamento de uma tensão, ou seja, se na vida cotidiana uma determinada ação implica num jogo de tensões específicas, o ator deve encontrar em seu próprio corpo um outro arranjo de forças que recrie, no palco uma ação semelhante".

Durante os laboratórios a pesquisadora buscou experimentar em si e com os/as participantes das Conduções os extremos do uso do espaço e da energia mobilizada com/para esse gestual extracotidiano e assim chegamos ao princípio da omissão:

O princípio da omissão relaciona-se à absorção da ação. Absorver uma ação consiste em restringir o espaço da ação, ou seja, conter a ação, como se esta retornasse ao estado de impulso. A ação pode ser 
absorvida das extremidades do corpo até o tronco e, depois ao nível do impulso, numa imobilidade dinâmica, chegando a um estado de omissão total, externa. Porém a intensidade da tensão empenhada na ação deve ser mantida ou intensificada em proporção inversa a tal retenção da amplitude da ação (SAUL, 2006, p. 22-23).

Possivelmente, neste momento o grande desafio é o/a ator/ atriz não se abandonar; consideramos também que a consciência alcançada por meio da omissão completa o princípio da equivalência e culmina com o acesso e reconhecimento do sats, que

[...] relaciona-se a uma mudança de tonicidade corporal, impulsos, mudanças de direção, diferença de potencial. Refere-se a um momento de transição, antes da efetuação de uma ação, quando o corpo já está decidido a realizar tal ação, ou seja, a ação está em estado potencial a ser realizada. O sats pode se relacionar, também, à imobilidade dinâmica, ou seja, à articulação de micromovimentos, numa contenção máxima da ação, que dilatam a presença, num corpo que está decidido (SAUL, 2006, p. 23).

Convém salientar que não estamos buscando aqui o treinamento físico para atores/atrizes na pretensão de torná-los resistentes como atletas ou dançarinos de Dança Afro ou de Orixá: a proposição é buscar outros caminhos que levem o/a atuante a um estado de consciência sobre o seu próprio corpo utilizando elementos característicos da corporeidade desta Iyabá.

Quando a dança de Orixá é transposta para o ambiente artístico, inicialmente no Afoxé, percebemos aqui alguns traços da própria transmissão de conhecimento do contexto sagrado, uma vez que, como aponta o professora Teodora de Araújo Alves (2006) ao falar da transmissão de saberes das danças afro-brasileiras, dentro de fora do campo litúrgico

[...] a dança, mais especificamente a afro-brasileira, busca compreender os saberes construídos étnica e culturalmente e nos faz perceber o corpo como espaço no qual se produz linguagem e existência no mundo e que muitos conhecimentos construídos e vivenciados pelos nossos antepassados acabaram se mantendo em nós, pela incorporação, ao longo das gerações (...) Refiro-me não apenas à herança genética, mas a um tipo de herança corporal, de dimensão expressiva, gestual, que nesse sentido, não é algo condicionado ao determinismo genético, mas que, na tessitura da vida, se envolve com o inusitado, com o conhecimento, com a pluralidade, com a transcendência, emergindo nas vivências, nos contatos, nos diálogos entre corpos que têm intencionalidades, expressividade, vida (...) a ideia de saberes incorporados entre as gerações ao nosso ver, transcende o momento da concepção e a hereditariedade de cada 
indivíduo. Trata-se de uma predisposição à realização de ações que, de certa forma, já forma realizados por gerações anteriores ou entre pessoas de gerações diferentes que convivem num mesmo tempo histórico, ou não. Portanto essa disposição não é algo apenas da natureza genética, mas também de cunho cultural e étnico. Afinal, a convivência, o diálogo estabelecido entre os indivíduos faz emergir a construção e transmissão desses saberes (ALVES, 2006).

Porém, nesta pesquisa, alguns aspectos importantes precisam ser ressaltados, primeiro consideramos que, por se tratar de um Afoxé, todos os participantes sejam iniciados no Candomblé, o que de fato, neste Afoxé específico não acontece, pois o mesmo não está vinculado oficialmente à nenhum terreiro e se propõe mais ao atendimento da comunidade negra, independente da religião. Segundo aspecto é que, quando os elementos coreográficos transitam da saída-de-orixá para as salas de ensaio de uma encenação há de se considerar que os/as atores/atrizes não fazem parte do Candomblé e que, possivelmente, não possuem nenhuma referência aprofundada da corporeidade da Dança de Orixá.

Então, se o indivíduo não necessariamente convive com o aspecto religioso dessa dança de Orixá, o que o aproxima dessa corporeidade? As motrizes culturais, aqui conceituadas por Zeca Ligiéro (2011) ao nos apontar que

O conceito de Motrizes Culturais será empregado para definir um conjunto de dinâmicas culturais utilizadas na diáspora africana para recuperar comportamentos ancestrais africanos. A este conjunto chamamos de práticas performativas e se refere à combinação de elementos como a dança, o canto, a música, o figurino, o espaço, entre outros, agrupados em celebrações religiosas em distintas manifestações do mundo afro-brasileiro (LIGIÉRO, 2011, p. 130).

\section{E complementa considerando que}

É o objetivo desse estudo, definir as principais dinâmicas nestas celebrações a saber: 1) o emprego de elementos performativos: canto, dança e música; 2) a utilização simultânea ou consecutiva do jogo e do ritual na mesma celebração; 3) o louvor aos ancestrais por meio do culto ou transe; 4) a presença de um mestre que guarda o conhecimento da tradição e que por meio da iniciação transmite o legado e que, na maioria dos casos, é também o performer que lidera o ritual e/ou celebração, e a 5) a utilização do espaço em roda, os performers se movimentam dentro do círculo enquanto a plateia assiste em volta (LIGIÉRO, 2011, p. 130).

Ou seja, esse conjunto tem a capacidade de ultrapassar o espaço do sagrado e se aproximar da comunidade e da prática artística, 
uma vez que possui elementos performativos que se aproximam do teatro, como já citado.

Trânsito do Candomblé para o teatro: o/a artista que dança-canta-conta

Para além da prática do ritual em si, outros pontos que aproximam uma saída-de-orixá do teatro são as convergências que se dão por ambos serem considerados como performances, pois, segundo Schechner (2013a),

[...] performance pode ser: comportamento ritualizado condicionado/permeado pelo jogo. Rituais são de uma forma de as pessoas lembrarem. Rituais são memórias em ação, codificadas em ações[...] $O$ jogo dá às pessoas a chance de experimentarem temporariamente o tabu, o excessivo e o arriscado (SCHECHNER, 2013a, p. 49).

Além disso, Schechner (2013b) argumenta que

A "performance" (...) é um "amplo espectro" de atividades que vão desde o ritual e o play (em todas as suas variedades desconcertantes e de difícil definição) até formas populares de entretenimento, festas, atividades da vida diária, os negócios, a medicina e os gêneros estéticos do teatro, da dança e da música. Não se tratava de afirmar que tudo nessas atividades é performativo, mas que cada uma delas tem qualidades que poderiam ser efetivamente analisadas e entendidas "como" performance (SCHECHNER, 2013b, p. 37).

A essas qualidades Schechner (2013b) chama de pontos de contato, que fazem com que qualquer coisa possa ser considerada como performance, mas que de fato só o é se estiver determinada dentro de um contexto cultural específico. Os pontos de contato discutidos por Schechner são seis, sendo:

1. Transformação do ser e/ou consciência

2. Intensidade da performance

3. Interação entre público e performer

4. A sequência da performance como um todo

5. A transmissão de conhecimentos performativos

6. Como as performances são geradas e avaliadas?

Pensando então que nessa investigação observei/observo ao menos dois tipos de performances - a ritual religiosa (acompanho a saída-de-orixá no Iansã) e a artística (nas práticas do Afoxé e nas aulas e laboratórios) - além dos pontos de contato também temos 
como identificar em ambas as práticas as sete fases da performance: treinamento, oficinas, ensaios, aquecimentos ou preparações imediatamente antes da performance, a performance propriamente dita, esfriamento e balanço (SCHECHNER, 2013b), mesmo que em cada contexto algumas dessas fases se tornem mais enfatizadas que as outras, essas sete fases serão retomadas mais a frente quando for me referir à estrutura da Condução do processo prático-criativo.

Além disso, Schechner (2013b) argumenta que esses seis pontos de contato não existirão isoladamente, estarão sempre em interação uns com os outros e que poderão ser analisados em termos de: "1 - Encorporação - a experiência como base do conhecimento nativo que é compartilhado por meio da performance (...) 2 - As fontes da cultura humana são performativas (...) 3 - O cérebro como um local de performance (SCHECHNER, 2013b, p. 39) ".

Vale salientar que, para esta investigação, os termos 1 e 2 terão maior relevância que o terceiro termo, já que o conhecimento nativo pode ser interpretado como o conhecimento existente nas saídas-de-orixá ou nas práticas do Afoxé, sendo essas duas manifestações performáticas e assim se dando sua transmissão e compartilhamento de conhecimentos ancestrais, e consequentemente, pensando nessa ancestralidade a noção de uma fonte cultural se pauta na resistência das performances afro-brasileiras onde seus praticantes cantam-contam-dançam-batucam.

Justo por estas aproximações e pela presença dos seis princípios apontados por Barba (2012) já citados, ao estruturar o roteiro de Condução das práticas em sala de ensaio com voluntários/as, buscamos seguir as seguintes fases: I - PREPARAÇÃO, II - AÇÃO e III - FINALIZAÇÃO, onde organizo em sete etapas, sendo elas:

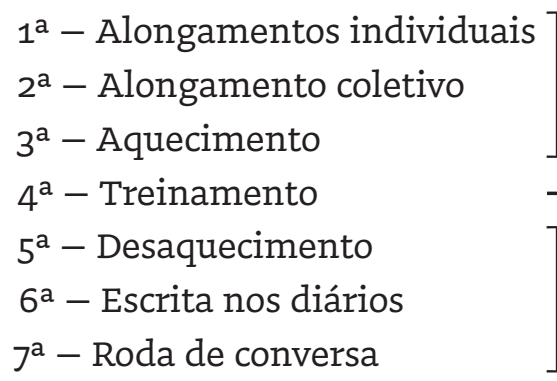

Essa estrutura foi pensada de modo que o trabalho se desenvolva numa crescente (Fase I), chegue ao seu ápice (Fase II) e decresça até seu fechamento (Fase III); também por este motivo, preferencialmente, o primeiro elemento a ser trabalhado será o VENTO, por ser o que mais se associa à Iansã quando se pensa nessa Iyabá, neste caso o alongamento e o aquecimento terão como foco exercícios de fortalecimento das panturrilhas - uma 
vez que nessa qualidade de energia o corpo tende a ficar apoiado na ponta dos pés - para os braços trabalhando, sobretudo com as articulações para execução de movimentos circulares e costas para que os membros superiores e inferiores busquem a sensação de flutuação com maior conforto e segurança.

O segundo elemento a ser trabalhado será o BÚFALO pelas características da qualidade de energia (mais aproximada do Animus) e pelas partes do corpo que mobilizadas - normalmente a parte inferior e deformação da coluna - de modo diferente ao que ocorre no VENTO. O terceiro elemento será então a BORBOLETA por mobilizar uma qualidade de energia bem distinta do BÚFALO, se manifestando mais como Anima.

No caso de trabalhar com os três elementos no mesmo dia, manterei essa sequência na tentativa de equalizar o uso da energia do/a artista da cena fazendo analogia à relação que pode se estabelecer entre fogo e água - dois elementos muito presentes na mitologia de Iansã - do seguinte modo: ESQUENTAR (Vento) $\rightarrow$ FERVER (Búfalo) $\rightarrow$ ARREFECER (Borboleta).

Para melhor esclarecer o que foi apontado aqui, trazemos a descrição de uma das Conduções realizadas como demonstração da pesquisa. Pelo curto tempo para a prática, em torno de trinta minutos, fez-se necessário trabalhar com os três elementos propostos sem maior aprofundamento e em apenas trinta minutos, sendo assim, dividimos o tempo em três etapas: I - PREPARAÇÃO, II - AÇÃO e III - FINALIZAÇÃO, as quais descrevemos a seguir.

\section{I - PREPARAÇÃO}

Inicialmente orientamos aos participantes que fizessem seus alongamentos e aquecimentos individuais. Em seguida pedimos que caminhassem pela sala, durante a caminhada solicitamos que trouxessem à memória imagens que sugerissem o vento (desde a brisa à tempestade), borboletas/mariposas e búfalos/bois/vacas. O passo seguinte foi pedir que experimentassem os verbos - em forma de movimento - LANÇAR, RECEBER e EMPURRAR. Consideramos interessante apontar que esses três verbos foram explorados com várias partes dos corpos dos participantes. Ao experimentarem os três movimentos, demos alguns comandos de expansão, velocidade e depois da diminuição do ritmo e do movimento até o retorno ao ponto zero, o corpo parado, mas ainda em estado de alerta. Nesse momento, pedimos que observassem como o corpo estava reagindo, quais grupos musculares haviam trabalhado, onde estavam as tensões. 
II - AÇÃO

Para o segundo momento, demos como orientação que experimentassem os verbos relacionados à Iansã sob a forma de ação, sendo eles CORTAR, ESPANAR e CHICOTEAR, pedindo aos participantes que se concentrassem nas ações em si mais do que nos possíveis objetos (espada, abanador e chicote) que poderiam estar usando.

Com as ações experimentadas sugerimos que retornassem às três primeiras imagens, as mesclando em suas ações sobre os seguintes comandos:

- Como seria o vento abanando/chicoteando/cortando?

- Como seria o movimento de uma borboleta abanando/ chicoteando/cortando?

- Como é o corpo desse búfalo abanando/chicoteando/cortando?

Nesta etapa as relações entre os participantes começaram a se estabelecer, então sugerimos que expandissem seus movimentos, explorando-os em totalidade e, gradativamente, que fossem minimizando seus movimentos, mas sem perder a sensação da energia que estava instaurada nos corpos.

III - FINALIZAÇÃO

Mantendo a energia das Danças Individuais de Iansã e sustentando as relações estabelecidas no momento anterior, pedimos para que retomassem as ações de LANÇAR, RECEBER e EMPURRAR, mantendo a observação nas mudanças ocorridas no corpo e na qualidade de movimento da etapa I para a etapa III. Foi interessante observar o quanto os verbos da Dança de Iansã potencializaram energeticamente os verbos do momento de Preparação. Para finalizar a prática, pedi aos participantes que diminuíssem seus movimentos até zerar e retornar ao estado do corpo cotidiano.

Finalizada a prática, fizemos alguns esclarecimentos quanto à escolha das imagens vento, borboleta e búfalo, para que fossem relacionadas ao arquétipo de Iansã e a escolha dos verbos CORTAR, ABANAR/ESPANAR e CHICOTEAR, que estão relacionados a algumas lendas e às ferramentas litúrgicas utilizadas na dança ritual.

Mesmo a prática sendo curta e, nesse caso, apenas um encontro, de pela observação foi possível perceber que, além de um treinamento pré-ensaio, a sistematização e condução podem vir a possibilitar ao performer a criação de uma partitura, pois, como são 
dados os elementos da Dança de Iansã através de comandos e não a coreografia da dança, o performer tem a liberdade de ressignificar esses momentos/verbos, uma vez que cada um tem em seu repertório corporal e imagético referências muito particulares de CORTAR, ESPANAR e CHICOTEAR, possibilitando até a construção das mais diversas dramaturgias como consequência dessa Dança Individual de Iansã.

O perfil dos/as participantes dessa Condução, apesar de diverso, tinha em comum o fato de serem artistas da cena - seja no teatro, na dança, no circo ou na performance - compreendendo assim que os referenciais de corporeidade eram muito particulares. Pela observação era possível identificar quais pessoas já traziam em sua memória referências da dança de Orixá pela estilização dos movimentos já nos primeiros instantes após ser dada a orientação, os/as demais, mesmo que com uma resposta, mas lenta e com a ação menos estilizada, acabavam aproximando seu gesto do que era executado fosse no campo do sagrado ou do já ressignificado nas coreografias do Afoxé.

Considerações finais: a forma que se transforma

Já que tomamos como base os princípios apontados por Barba (2012), compreendemos que a potencialização do trabalho de atores e atrizes durante a preparação para uma montagem cênica permeia a (re)descoberta de formas diversas de utilização do próprio corpo, pensando nele para além do suporte, da ferramenta de trabalho deste/a artista. Parte destes princípios se baseiam na deformação ${ }^{9}$ do corpo cotidiano para o acesso ao corpo extracotidiano, que o próprio Barba busca nas danças codificadas do extremo oriente a base de seu treinamento.

Se tratamos então de uma deformação do corpo cotidiano para alcançar o corpo extracotidiano que potencializa estados de atenção e de energia nos/as artistas da cena, podemos sim recorrer as danças afro-ameríndias, no caso específico desta pesquisa, ao observar não-iniciados executando ações que são conduzidas pela observação do corpo dançante no Candomblé e no Afoxé, percebemos que, além do acesso à Gestualidade Ancestral e a expansão do repertório corporal destes indivíduos, percebemos suas referências e processos epistêmicos corporeificados, pois o Eu-Búfalo experimentado por um artista circense possui determinadas especificidades que são diferentes do Eu-Búfalo do ator que durante toda uma vida trabalhou com bases no teatro brechtiano, que consequentemente será diferente do Eu-Vento de uma bailarina de
Considerando neste caso a deformação como o uso do corpo com diferentes apoios e com posturas diferentes do corpo cotidiano, dentre as posturas mais recorrentes, podemos citar as costas arqueadas, o caminhar com as bordas dos pés ou em nível médio ou baixo. 
dança moderna, que será diferente do Eu-Borboleta do brincante de Boi-de-reis.

Conclui-se que, independentemente de sua trajetória ou dos seus acessos às expressões da religiosidade ancestral afro-ameríndia, algo te ajuda a acessar seus gestos ancestrais, seja pela música, seja pela sugestão das imagens, ou pela repetição do movimento. Seja qual for o caminho, ele restaura o que foi incorporado e mobilizado por essas motrizes/matrizes de um corpo afro-ameríndio, de um ser/estar no mundo brasileiro ancestral e contemporâneo. 


\section{REFERENNCIAS}

ALVES, Teodora de Araújo. Herdanças de corpos brincantes: os saberes da corporeidade em danças afro-brasileiras. Natal: EDUFRN - 2006.

BARBA, Eugenio, SAVARESE, Nicola (Org). A Arte Secreta do Ator - Um dicionário de Antropologia Teatral. São Paulo: É Realizações - 2012.

BARBA, Eugenio. A Canoa de Papel - Tratado de Antropologia Teatral. Brasília: Dulcina Editora - 2009.

BENY, Daniela. A codificação corporal da Dança de Iansã nas coreografias do Afoxé Oju Omim Omorewá, 68p, Especialização em Antropologia, Universidade Federal de Alagoas/UFAL, Maceió -2014 .

HUIZINGA, Johan. Homo Ludens - O jogo como elemento da cultura. São Paulo: Perspectiva, 2008.

LIGIÉRO, Zeca. O conceito de "motrizes culturais" aplicado às práticas performativas afro-brasileiras. In: Revista Pós Ciências Sociais, Maranhão - v.8, n. 16, 2011.

MERLEAU-PONTY, Maurice. Fenomenologia da Percepção. São Paulo: Martins Fontes - 1999.

SANTOS, Inaicyra Falcão. Corpo e Ancestralidade: ressignificação de uma herança cultural. In: ABRACE, V., 2008. Belo Horizonte. Anais V Congresso: Criação e Reflexão Crítica. Disponível em: <http://www.portalabrace.org/vcongresso/textos/pesquisadanca/Inaicyra\%20Falcao\%20dos\%20Santos\%20-\%20Corpo\%20 e\%20Ancestralidade\%20resignificacao\%20de\%20uma\%20 heranca\%20cultural.pdf.> Acesso em: 19 de Março de 2017.

SAUL, Luciana. Rituais do Candomblé - Uma inspiração para o trabalho criativo do ator. 276 p. Dissertação de Mestrado. CAC/ ECA/USP. São Paulo, 2006.

SCHECHNER, Richard. O que é performance?. In O Percevejo, ano 11, 2003, n. 12, p. 25 a 50.

SCHECHNER, Richard. (Org. de Zeca Ligiéro). Performance e Antropologia de Richard Schechner. Rio de Janeiro: Mauad X Editora, $2013 a$.

SCHECHNER, Richard. "Ponto de Contato" revisados. In: DAWSEY, John C.; MÜLLER, Regina P; HIKIJI, Rose Satiko G.; MONTEIRO, Marianna F. M. (Org). Antropologia e performance - ensaios Napedra. São Paulo: Terceiro Nome, 2013b, p. 37-65.

TAYLOR, Diana. O Arquivo e O Repertório - Performance e memória cultural nas Américas. Belo Horizonte: Editora UFMG, 2013.

ZENICOLA, Denise. Ubuntu (Partilhamento) In Moringa - Artes do Espetáculo. V.2, n.2, p. 85-92, 2011. 